\title{
Assessment of the Flexural Behavior of Concrete Block Masonry Beams
}

\author{
V.G. Haach ${ }^{\mathrm{a}}$, G. Vasconcelos ${ }^{\mathrm{b}}$ and P.B. Lourenço.c \\ ISISE, Department of Civil Engineering, University of Minho, Campus de Azurém \\ 4800-058 Guimarães, Portugal \\ avghaach@civil.uminho.pt, bgraca@civil.uminho.pt, ${ }^{\mathrm{c} p b \mid @ c i v i l . u m i n h o . p t ~}$
}

Keywords: Concrete block reinforced masonry; Masonry beams, Construction technology; Bed joint reinforcement; Flexural testing.

\begin{abstract}
This paper focus on the experimental flexural behavior of masonry beams. In the sequence of the development of a novel structural solution for reinforced masonry walls at University of Minho, different possibilities for the construction of lintels with concrete block masonry have been tested. Reinforced concrete beams with three and two hollow cell concrete blocks and with different reinforcement ratios have been built and tested in a four point loading test configuration. It was clear that horizontal bed joint reinforcement increased the ultimate flexure capacity as well as the ultimate deflection, leading to much more ductile responses. Moreover, it was also clear that a more deep analysis should be made regarding the role of the compressive strength of masonry in the parallel direction to the bed joints on the global behavior of the masonry beams.
\end{abstract}

\section{Introduction}

Structures must be designed to resist lateral loads from wind and earthquakes when they are located in seismic regions. Shear walls are the elements that resist in-plane loads. When openings exist, they act together with the lintels, which are linear elements over the doors or windows that connect the shear walls. Lintels are responsible for the distribution of vertical loads over openings. They also act as the coupling elements between masonry piers and, thus, play an important role in the distribution of lateral actions among the shear walls in masonry buildings. Masonry lintels are subjected to shear and flexure forces and, according to several authors, the design of masonry beams can be performed using the ultimate strength design method similar to what is used in reinforced concrete beams [1-4]. Nevertheless, the anisotropy of masonry, generated mainly by mortar joints which are planes of weakness, makes the behavior of masonry beams more complex. For example, in case of masonry beams the upper compression stresses develops in the direction parallel to the bed joints, contrarily to the most common structural masonry elements, in which compression develops in the direction perpendicular to the bed joints.

It should be stressed that additional research effort is needed in these structural masonry elements, given the scarce information available in the literature. Therefore, a large experimental program was developed aiming at improving the understanding on the behavior of masonry beams under flexure, for which four point load bending tests were considered. The simplicity on the arrangement of the test setup and on the interpretation of results represents an important advantage. Horizontal and vertical prefabricated reinforcements were used in bed joints and vertical cores of units respectively to evaluate their influence in the flexural behavior of the masonry beams.

\section{Experimental Program}

The experimental program was carried out at Structural Laboratory of University of Minho (LEST) aiming at evaluating the flexural behavior of reinforced masonry beams through the four point load bending test configuration. Fourteen masonry beams were built with different geometry of units and distinct horizontal reinforcement distribution. Besides the experimental behavior of the masonry 
beams, an experimental campaign was also performed in order to obtain the mechanical properties of the masonry materials and of the masonry as a composite material.

Masonry Specimens. Masonry beams were built with three and two hollow cell concrete blocks, whose shape and geometry are shown in Fig. 1a. The first blocks have a central cell where vertical reinforcements can be positioned. Due to laboratory limitations, half scale concrete blocks were produced (roughly $200 \mathrm{~mm}$ length, $100 \mathrm{~mm}$ width and $100 \mathrm{~mm}$ height). Modified general purpose mortar with a binder to aggregate ratio of 1:3 (cement:sand) was used in the construction of the beams in order to achieve a compressive strength of mortar of about $10 \mathrm{MPa}$, which is a recommend value for masonry structures located in seismic areas [5,6]. Truss type reinforcements were used in bed joints and in the internal cores of the concrete blocks, see Fig. 1a. Masonry beams were built with dry vertical joints, when three hollow cell masonry units were used, and common mortar filled vertical joints were considered in case of two hollow cell masonry units. Masonry beams were built with 4 courses in height and 7 blocks in length with $8 \mathrm{~mm}$ thickness for the vertical and horizontal joints, corresponding to a height to span ratio of 0.29 , see Fig. 1b. A summary of the typologies of the masonry beams is indicated in Table 1 . Here, $\mathrm{F}$ denotes flexure, $2 \mathrm{C}$ and $3 \mathrm{C}$ relates the type of unit, D5 and D3 denotes the diameter of bed joint reinforcement $\left(\phi_{h}\right)$ and UM means unreinforced masonry. In order to avoid shear failure at the supports, two vertical reinforcements with $5 \mathrm{~mm}$ of diameter (indicated in Fig. 1b with VR) were introduced at the vertical cores of the concrete blocks between the supports and the load application points.
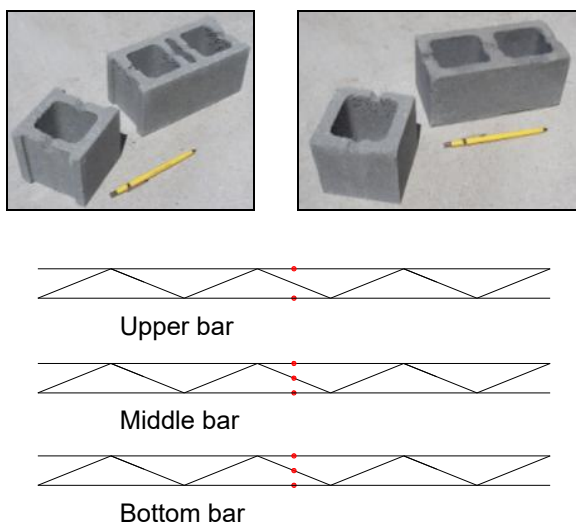

(a)

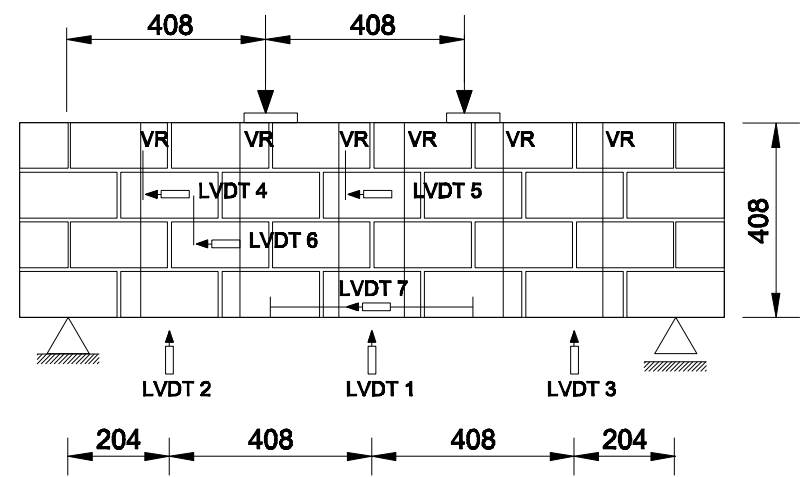

(b)

Fig. 1. Details of the experimental program; (a) concrete masonry units and location of the strain gauges on the horizontal reinforcements (b) geometry, loading and instrumentation of beams.

(Dimensions are in $\mathrm{mm}$ ).

Table 1- Details of masonry beams.

\begin{tabular}{lccccccc}
\hline \multicolumn{1}{c}{ Beam } & $\begin{array}{c}\emptyset_{\mathrm{h}} \\
{[\mathrm{mm}]}\end{array}$ & $\begin{array}{c}\rho_{\mathrm{h}} \\
{[\%]}\end{array}$ & $\begin{array}{c}\text { Dimensions } \\
{[\mathrm{mm}]}\end{array}$ & Beam & $\begin{array}{c}\emptyset_{\mathrm{h}} \\
{[\mathrm{mm}]}\end{array}$ & $\begin{array}{c}\rho_{\mathrm{h}} \\
{[\%]}\end{array}$ & $\begin{array}{c}\text { Dimensions } \\
{[\mathrm{mm}]}\end{array}$ \\
\hline F-3C-UM & - & - & $1407 \times 404 \times 100$ & F-2C-UM & - & - & $1420 \times 408 \times 94$ \\
F-3C-D5-C & 5 & 0.097 & $1407 \times 404 \times 100$ & F-2C-D5-C & 5 & 0.102 & $1420 \times 408 \times 94$ \\
F-3C-D5-D & 5 & 0.292 & $1407 \times 404 \times 100$ & F-2C-D5-D & 5 & 0.307 & $1420 \times 408 \times 94$ \\
F-3C-D5-D-M & 5 & 0.292 & $1407 \times 404 \times 100$ & F-2C-D5-D-M & 5 & 0.307 & $1420 \times 408 \times 94$ \\
F-3C-D3-C & 3 & 0.035 & $1407 \times 404 \times 100$ & F-2C-D3-C & 3 & 0.037 & $1420 \times 408 \times 94$ \\
F-3C-D3-D & 3 & 0.105 & $1407 \times 404 \times 100$ & F-2C-D3-D & 3 & 0.111 & $1420 \times 408 \times 94$ \\
F-3C-D3-D-M & 3 & 0.105 & $1407 \times 404 \times 100$ & F-2C-D3-D-M & 3 & 0.111 & $1420 \times 408 \times 94$ \\
\hline
\end{tabular}

Two vertical reinforcements were added at mid-span (specimens indicated with $\mathrm{M}$ ) in order to assess its contribution to improve the flexural behavior of the beams such as the increase on the 
flexural strength and the prevention of vertical splitting stresses developed at the upper compressive region due to high compressive stresses. The letters $\mathrm{C}$ and $\mathrm{D}$ indicates if horizontal reinforcement was placed only at the first course or distributed along the height of the masonry beam respectively. Bed joint reinforcement ratio, $\rho_{h}$, was the main parameter analyzed in the tests.

Test Setup, Procedures and Instrumentation. The beams were tested through a four point loading configuration in order to ensure that the central region of the panel was in pure flexure, as recommended in [7], see Fig. 1b. Masonry panels were laid on two steel roller supports with a base of $100 \mathrm{~mm} \times 100 \mathrm{~mm}$ in order to avoid the concentration of stresses. One of the supports was fixed in a steel profile anchored at the slab of the laboratory, see Fig. 2a. Special attention had to be taken in order to avoid torsional and frictional stresses at the free support. For this reason, a roller support was placed in the direction of the beam and two Teflon sheets with grease in between were located at the base of the support, see Fig. $2 b$.

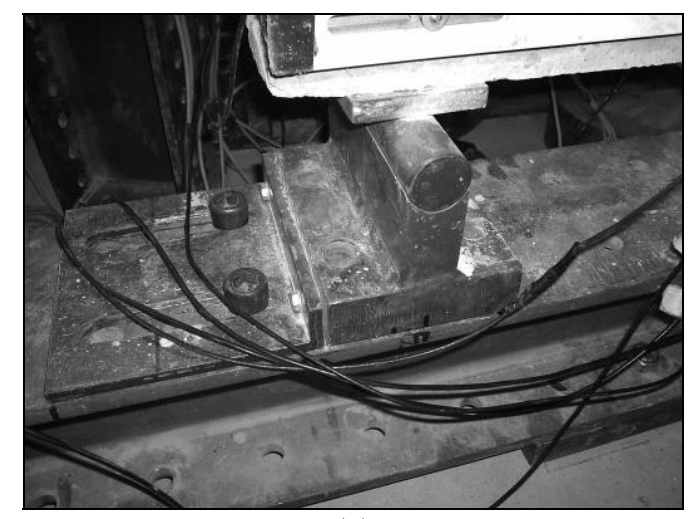

(a)

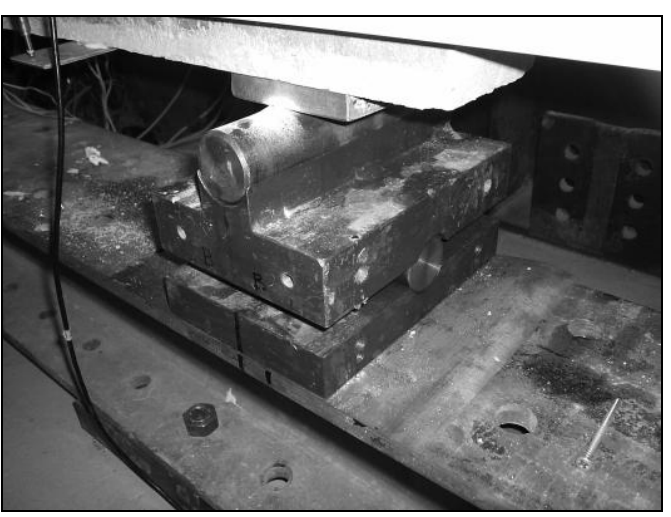

(b)

Fig. 2. Details of the boundary conditions of masonry beams: (a) fixed support; (b) free support.

Half-rollers were positioned between the vertical actuator and the steel beam that distribute the load by two points of application, and between the steel beam and the masonry beam, in order to avoid frictional efforts and concentration of stresses at the load application points.

The masonry beams were cured at the laboratory basement with relative air humidity of approximately $80 \%$. The monotonic tests were carried out under displacement control at a rate of $5 \mu \mathrm{m} / \mathrm{s}$ by means of an external LVDT connected to the vertical actuator. In order to ensure proper curing of the specimens, the tests were carried out 28 days after construction. The displacements of the masonry beams were measured by means of a set of LVDTs, whose localization is indicated in Fig. 1b. LVDTs 1, 2 and 3 measured the deflections of the beams, whereas LVDTs 4, 5 and 6 intended to measure the slippage of the horizontal joints. The possible opening of a vertical flexural crack at vertical joints at mid-span of the beams was detected by LVDT 7. Strain-gauges were glued to the horizontal reinforcements at the mid-span of the beam according to the configuration indicated in Fig. 1a in order to measure the tensile strains and thus to assess the reinforcement contribution to the response of the masonry beams.

\section{Results}

The experimental tests carried out in masonry beams provided important indicators about their flexure behavior, even if some friction developed at the free support [8]. The analysis of the results is presented next in terms of failure modes and force-displacement diagrams.

Failure Modes. Flexure was the failure mode of most masonry beams (F-3C-UM, F-2C-UM, F3C-D3-C, F-2C-D3-C, F-3C-D3-D, F-3C-D3-D-M, F-2C-D3-D and F-2C-D3-D-M). In spite of the presence of vertical reinforcements next to the supports, masonry beams with the highest horizontal 
reinforcement ratio failed in shear (F-3C-D5-D, F-3C-D5-D-M, F-2C-D5-D and F-2C-D5-D-M). Specimens F-3C-D5-C and F-2C-D5-C exhibited a mixed failure mode, see Fig. 3.

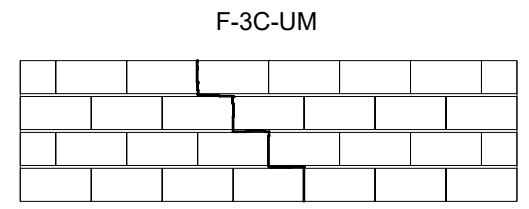

F-3C-D3-D

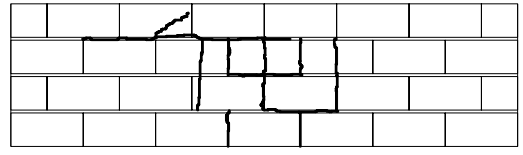

(b)

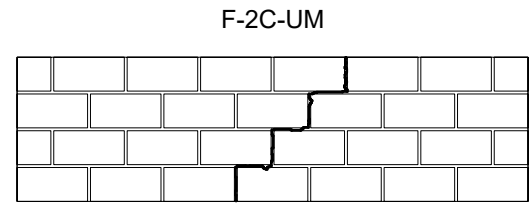

(a)

F-2C-D5-D

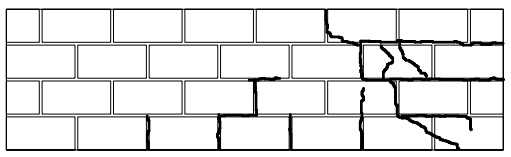

(c)

Fig. 3. Common cracking pattern of masonry beams: (a) unreinforced masonry beams, (b) typical flexural cracking patterns in reinforced masonry beams and (c) typical shear cracking patterns in reinforced masonry beams.

The flexural cracking pattern was characterized by the opening of initial vertical cracks along vertical joints at the bottom of the beam in the central region under pure flexure. The evolution of the vertical crack opening could be detected through the results of LVDT 7, which was located at the bottom of the beams, see Fig. 1. Results showed that the flexural crack closed during the postpeak regime in specimens failing in shear, which is revealed by the snap-back behavior of the loaddisplacement diagrams shown in Fig. 4. In specimens failing by flexure the flexural crack opened continuously until the end of the test.

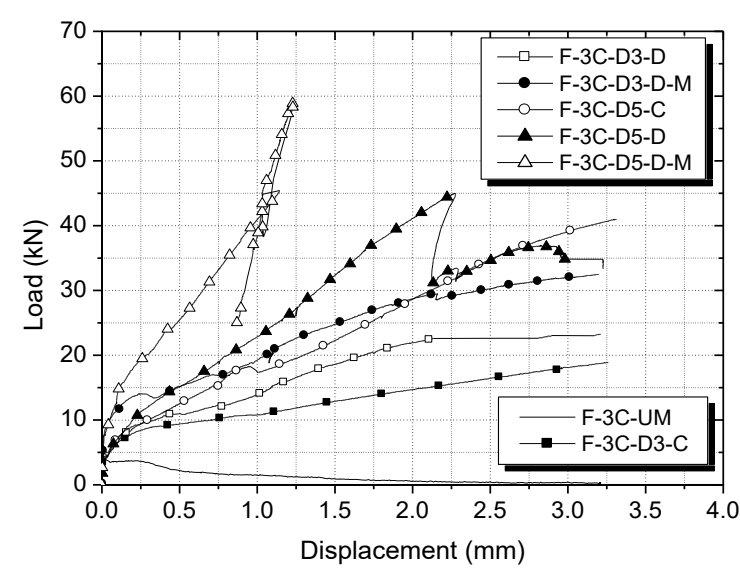

(a)

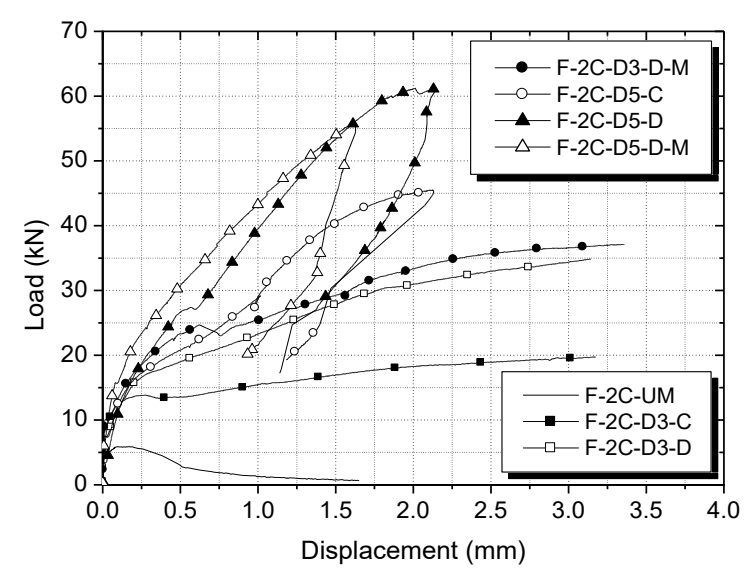

(b)

Fig. 4. Results of the LVDT 7 (opening of flexural cracks): (a) 3C-units and (b) 2C-units.

In case of unreinforced masonry (F-2C-UM and F-3C-UM), the flexural crack pattern is characterized by a stepped crack along the height of the beam resulting from the sudden propagation of the vertical crack developed at the bottom central region of the beam. The resisting mechanism of the masonry beams built with the two distinct concrete blocks appeared to be influenced by the masonry bond as they appear to be quite different. The masonry beams built with the three cell units have dry stacked vertical joints, whereas the masonry beams with two cell concrete blocks have filled vertical joints. In case of two cell blocks and filled vertical joints, the opening of the flexural crack results from the achievement of the tensile strength of the central vertical unit-mortar interface at the first course. Its propagation up to the top region results from the combination of the attainment of the tensile and shear strength of the unit-mortar interfaces. In masonry beams with three cell concrete units the propagation of the stair stepped flexural crack is essentially due to the achievement of the shear strength of the unit-mortar interface, since the dry 
vertical joints have no tensile strength. With the increase of the applied vertical load, vertical joints of the second course exhibit a tendency to open, which was prevented by the shear stresses of the horizontal unit-mortar interface until the attainment of the corresponding shear strength, see Fig. 5. The flexural cracking patterns follows almost exclusively the unit-mortar interfaces due to their low resistance, when compared to the tensile strength of the concrete units.

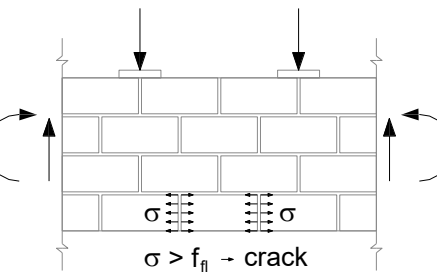

(a)

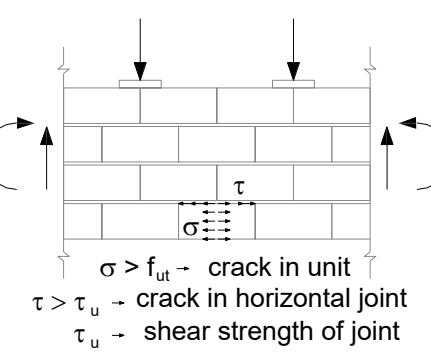

(b)

Fig. 5. Resistance mechanisms of unreinforced masonry beams under flexure:

(a) F-2C-UM and (b) F-3C-UM.

In case of reinforced masonry beams, after the opening of the vertical joints at the first course, strains measured in horizontal reinforcements considerably increase and decrease along the height of the beam. The yielding of these reinforcements is particularly visible in specimens where only a horizontal reinforcement of $3 \mathrm{~mm}$ diameter is placed at the first course (F-3C-D3-C and F-2C-D3C). It is observed that horizontal bars exhibited a decrease on strains near failure of the beam, which can be attributed to the unloading of the steel bars after its breakage [8], see Fig. 6a. Specimens with horizontal reinforcements distributed along the height of the beams, F-3C-D3-D, F-3C-D3-DM, F-2C-D3-D and F-2C-D3-D-M, exhibited also a typical flexural cracking with the same cracking pattern. Apart from specimen F-3C-D3-D-M, whose horizontal reinforcement broke at first and second courses, all of the abovementioned specimens exhibited breakage of horizontal reinforcements only at the first course. It is observed that in general the horizontal reinforcements placed at first and second courses present tensile strains, whereas the reinforcement of the third course exhibit compressive strains, as expected, Fig. 6b. The introduction of vertical reinforcements at mid-span of the beams increased their flexural strength, due to great extent to the filling of cells with mortar, which generated a reduction of strains in reinforcements of the first course at mid-span [8]. The positioning of these reinforcements induced also a change on the cracking pattern, moving the flexural failure for the third part of the beam.

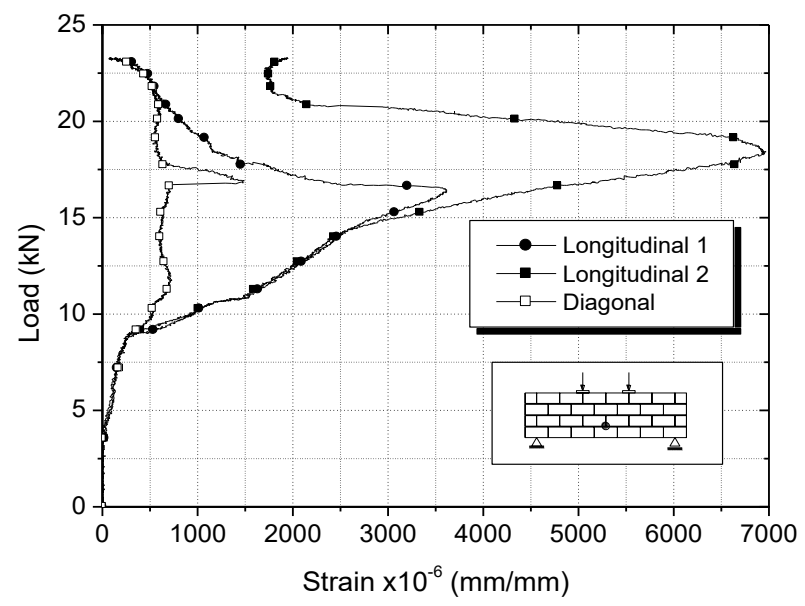

(a)

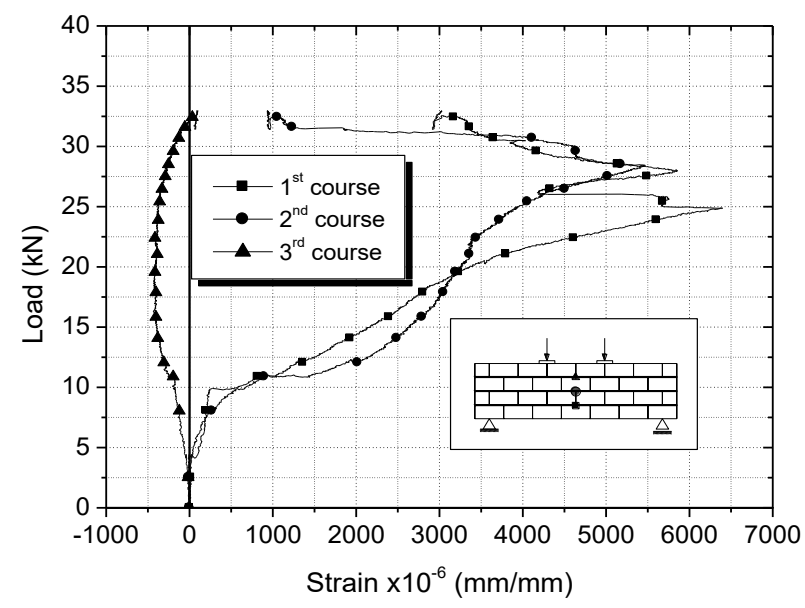

(b)

Fig. 6. Results of the LVDT 7 (opening of flexural cracks): (a) 3C-units and (b) 2C-units. 
In case of specimens with horizontal reinforcements of $5 \mathrm{~mm}$ diameter (F-3C-D5-C and F-2CD5-C) located only at the first course, vertical cracks also initiated at the central vertical joints and horizontal reinforcement yielded. However, shear mode with characteristic diagonal cracks also developed in spite of the presence of vertical reinforcements near the support. After diagonal cracking, vertical reinforcements positioned between the load application and the supports ensured an enhanced distribution of stresses. Specimens with horizontal reinforcements placed at all bed joints failed predominantly in shear, with the opening of diagonal crack between the support and the load application point, see Fig. 3c. The failure by shear diagonal cracking was also characterized by sliding of the units at the border vertical edges over the bed joint. This behavior was more remarkable in specimens with horizontal reinforcement distributed along the height of the beams due to the higher ultimate load and thus to higher shear stresses. The sliding at the unit-mortar interface is attributed to the achievement of the shear strength of the unit-mortar interface due to shear stresses in the direction perpendicular to the cross section of the beams.

The presence of reinforcements distributed along the height of the specimens produced an increase of the resistance of the beam, resulting in a higher resisting moment and, thus, in higher stresses at the upper compressive zone of the beam. These high compressive stresses induce cracking in the webs of the concrete blocks and separation of the top masonry course from the mortar bed joint, see Fig. 7. The vertical reinforcements at the middle span of the panels produced a good control of the cracking and reduced the trend for separation of the top course, improving the overall behavior of masonry beams, especially where flexure is preponderant. Diagonal cracking is followed by sliding of the units between the crack and the free edge of the beam.
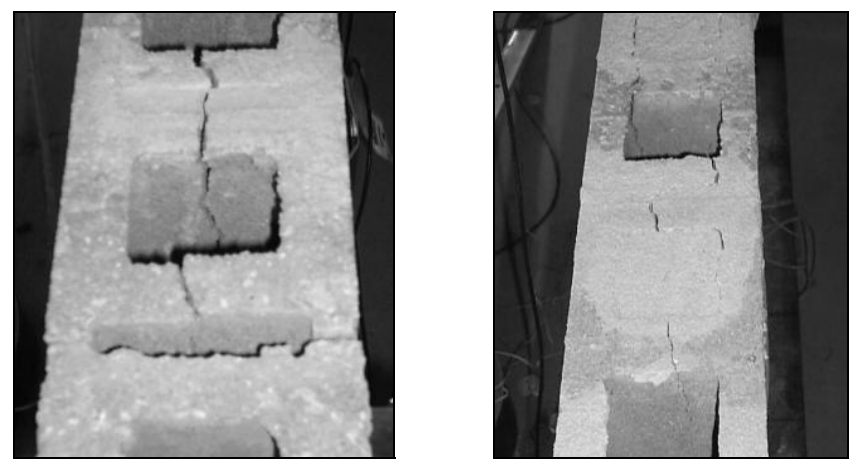

Fig. 7. Cracks in webs of blocks due to the high compressive stresses.

Force-Displacement Diagrams and Crack Limits. The force-displacement diagrams exhibiting the global behavior of the tested beams are shown in Fig. 8 . In general, three phases characterize the force-displacement diagrams of masonry beams.

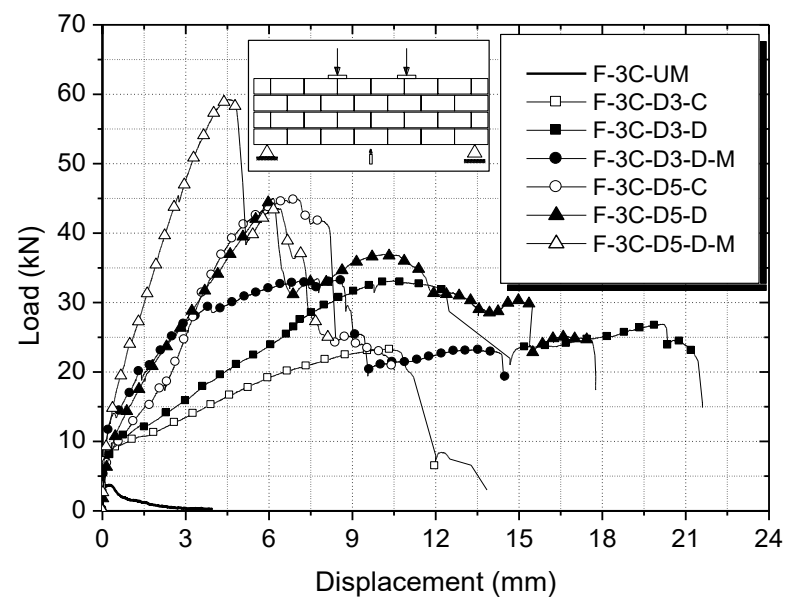

(a)

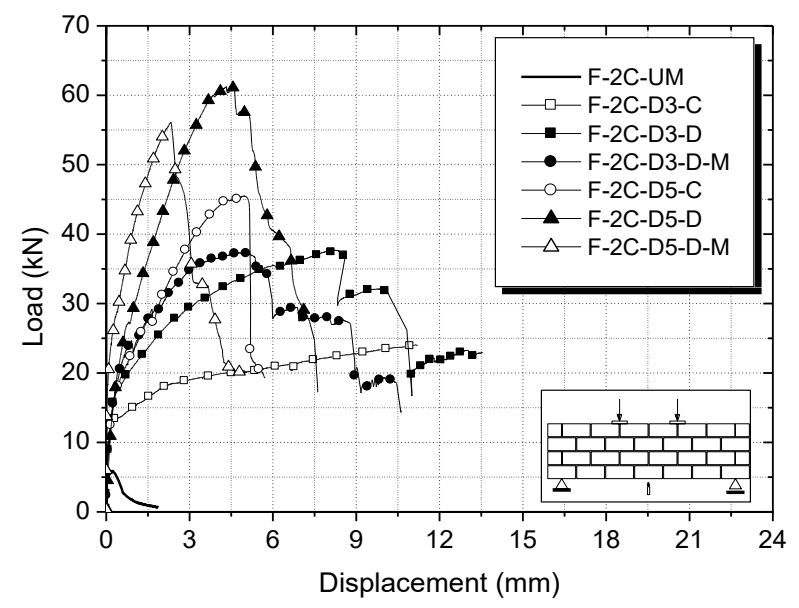

(b)

Fig. 8. Force-displacement diagrams of beams: (a) built with 3C-units and (b) built with 2C-units. 
There is an initial elastic behavior corresponding to a high initial stiffness with small vertical deflections. The second stage is characterized by the opening of flexural cracks at the unit-mortar interface located at mid-span, which is associated to an abrupt decrease on the stiffness and to an increase on the load up to the achievement of the maximum strength of the beam. The decrease on the stiffness is particularly evident on specimens behaving in flexure.

The stiffness at the second stage depends on the horizontal reinforcement ratio and on the presence of vertical reinforcements at the middle span, with an increase with increasing horizontal reinforcement ratio and with the addition of vertical reinforcement at mid-span. After flexural cracking, load transfer from the masonry to the horizontal reinforcements occurs, being the resisting mechanism composed by the tensile strength of the reinforcements and the compressive strength of masonry. The third stage is characterized by the reduction on resistance with increasing displacements. The failure of beams can occur by yielding of reinforcement, crushing of masonry in the upper compressed part or by diagonal shear cracking.

Unreinforced masonry beams present very low flexural strength and very brittle behavior, even if slighter higher strength was obtained for beams with filled vertical joints and two cell blocks. After flexural cracking at the bottom course a sudden stair stepped crack progresses to the compressed edge of the beams leading to an abrupt failure. It is observed that the introduction of horizontal reinforcement, the increase on its ratio and its distribution along the height plays a key role on the increase of the strength and ductility of the masonry beams, in any of the adopted masonry bonds. Considerable higher resistance of reinforced beams at bed joints is obtained, in comparison with unreinforced masonry beams. Besides, it is clear that the strength of beams increases as the horizontal reinforcement ratio increases.

The specimens predominantly governed by flexure presents considerable higher ductility than the specimens where diagonal shear cracking takes the central role on the behavior of the beams, with higher deflection corresponding to the maximum resistance, considerable higher ultimate deflection and smoother post-peak branch. It should be stressed that masonry beams built with three hollow cell concrete units are remarkably more ductile than masonry beams built with two hollow cell units and filled vertical joints. This appears to be related with the type of units and with the compression in the direction parallel to the bed joints, which is much more ductile for masonry built with three cell units and dry vertical joints [8,9] .

Results showed that there is a trend, for the horizontal reinforcements and vertical reinforcements placed at mid-span, to increase the force corresponding to the flexural cracking, $f_{f c r}$, in both masonry bonds, see Table 2, meaning that these reinforcements improve the tensile strength of masonry.

Table 2 - Cracking and maximum loads for the masonry beams.

\begin{tabular}{|c|c|c|c|c|c|c|c|c|c|}
\hline Beam & $\begin{array}{c}f_{f c r} \\
{[\mathrm{kN}]}\end{array}$ & $\begin{array}{c}f_{d c} \\
{[\mathrm{kN}]}\end{array}$ & $\begin{array}{c}f_{m} \\
{[\mathrm{kN}]}\end{array}$ & $\begin{array}{c}f_{t f} \\
{[\mathrm{kN}]}\end{array}$ & $\begin{array}{c}f_{t s} \\
{[\mathrm{kN}]}\end{array}$ & Beam & $\begin{array}{c}f_{f c r} \\
{[\mathrm{kN}]}\end{array}$ & $\begin{array}{c}f_{d c} \\
{[\mathrm{kN}]}\end{array}$ & $\begin{array}{c}f_{m} \\
{[\mathrm{kN}]}\end{array}$ \\
\hline F-3C-UM & 4.1 & - & 4.1 & - & - & F-2C-UM & 5.1 & - & 5.9 \\
\hline F-3C-D3-C & 3.8 & - & 23.3 & 13.4 & 41.3 & F-2C-D3-C & 8.9 & 18.9 & 24.1 \\
\hline F-3C-D3-D & 4.4 & - & 33.2 & 18.0 & 41.3 & F-2C-D3-D & 7.5 & 24.4 & 37.7 \\
\hline F-3C-D3-D-M & 8.7 & - & 33.3 & 18.0 & 41.3 & F-2C-D3-D-M & 10.1 & 21.9 & 37.4 \\
\hline F-3C-D5-C & 4.8 & 15.7 & 44.9 & 13.6 & 49.7 & F-2C-D5-C & 7.4 & 24.8 & 45.5 \\
\hline F-3C-D5-D & 5.2 & 23.1 & 45.0 & 19.6 & 49.7 & F-2C-D5-D & 3.5 & 41.7 & 61.2 \\
\hline F-3C-D5-D-M & 7.6 & 18.2 & 59.3 & 19.6 & 49.7 & F-2C-D5-D-M & 7.8 & 22.3 & 56.1 \\
\hline
\end{tabular}

However, the presence of vertical reinforcements at mid-span appears to anticipate the diagonal cracking of the beams, leading to lower diagonal cracking forces, $f_{d c}$. This can be associated to the increasing level of compressive stresses at upper region of beams leading to the increase of compressive stresses on diagonal struts between the load application point and supports. Comparing 
the experimental, $f_{m}$, and theoretical values of the maximum load associated to flexure and shear resisting mechanisms, $f_{t f}$ and $f_{t s}$, calculated according to [5], it is clear that in case of masonry beams failing in flexure, the experimental strength is considerable higher than the theoretical value, see Table 2. This can be attributed to the axial stresses generated by the certain level of restriction due to friction forces at the free support.

\section{Concluding Remarks}

This paper presents the details and results of an experimental campaign carried out on a set of masonry beams that can be used as lintels above openings, by using the four point load bending configuration. The type of concrete blocks, masonry bonds and horizontal and vertical reinforcement ratios were the main variables analyzed.

Results indicated that unreinforced masonry beams present very low tensile strength and very brittle failure. It is observed that the addition of bed joint reinforcement improves the flexure behavior of masonry beams, by increasing the capacity of these elements to resist tensile stresses, and the deformation capacity, by providing a better distribution of cracks leading to the delay the opening of diagonal cracking.

The shape of the concrete units and masonry bond have no significant influence on the flexural resistance of masonry beams but play an important role on ductility. Masonry beams built with three hollow cell concrete masonry units exhibit much higher ultimate deflection, when compared to the masonry beams built with two cell concrete blocks.

\section{Acknowledgements}

This work was partly supported by contract DISWALL - "Development of innovative systems for reinforced masonry walls" - COOP-CT-2005-018120 from the European Commission. The first author was supported by the Programme AlBan, the European Union Programme of High Level Scholarships for Latin America, Scholarship no E06D100148BR.

\section{References}

[1] F.M. Khalaf, J.I. Glanville, M. El Shahawi: A study of flexure in reinforced masonry beams, Concrete International, 5(6), 1983, 46-53.

[2] A.W. Hendry: Structural Masonry, MacMillan Press LTDA, London, UK, 1998.

[3] R.G. Drysdale, A.A. Hamid, L.R. Baker: Masonry structures: behaviour and design, The Masonry Society, Boulder, Colorado, USA, 1999.

[4] N. Taly: Design of reinforced masonry structures, McGraw-Hill, New York, USA, 2001.

[5] EUROPEAN STANDARD. EN 1996-1-1, Eurocode 6 - Design of masonry structures - Part11: General rules for reinforced and unreinforced masonry structures. 2005.

[6] V.G. Haach, G. Vasconcelos, P.B. Lourenço, G. Mohamad: "Study of a mortar to use as infill and embedding", Proceedings of 10th North American Masonry Conference, St. Louis, Missouri, USA, 2007, 530-541.

[7] EUROPEAN STANDARD. EN 846-9, Methods of tests for ancillary components for masonry - Part 9: Determination of flexural resistance and shear resistance of lintels, 2000.

[8] V.G. Haach: Development of a design method for reinforced masonry subjected to in-plane loading based on experimental and numerical analysis, $\mathrm{PhD}$ Thesis, University of Minho, (2009).

[9] V.G. Haach, G. Vasconcelos, P. Lourenço: Influence of the geometry of units and of the filling of vertical joints in the compressive and tensile strength of masonry, Materials Science Forum, (in this issue). 